\title{
BEYOND THE BORDERS OF GLOBALIZATION EU-AFRICA, ECONOMY AND CONFLICT
}

\author{
Şipeţean Cristian', \\ Ivan Oana Raluca ${ }^{2}$
}

\begin{abstract}
Globalization in the literature can be described as an absence of barriers and borders of trade (Ohmae, 1995). Starting from this definition, and expanding the sides of this theory, we can generalize that globalization is an increase of permeability in the traditional economical boundaries including cultural and physical boundaries such as nation states and national economies, organizations, cultural norms and assumptions. More over, the lack of borders and frontiers creates a greater swift between the political, economical, technological and cultural spheres, on the international scene. In other words, the classic economy has changed into a highly dynamic market, which affects the stability of the work environment in different organizations or industries. The negative effects of globalization are multiple, and they refer to the effort to stay competitive on the market, and that increases the rates of mergers and acquisitions, privatizations, etc.
\end{abstract}

Key words: globalization, borders, conflict, economy.

JEL code: E00.

\section{Introduction:}

Globalization in the literature can be described as an absence of barriers and borders of trade (Ohmae, 1995). Starting from this definition, and expanding the sides of this theory, we can generalize that globalization is an increase of permeability in the traditional economical boundaries including cultural and physical boundaries such as nation states and national economies, organizations, cultural norms and assumptions. More over, the lack of borders and frontiers creates a greater swift between the political, economical, technological and cultural spheres, on the international scene. In other words, the classic economy has changed into a highly dynamic market, which affects the stability of the work environment in different organizations or industries (Rosenbaum, 1998). The negative effects of globalization are multiple, and they refer to the effort to stay competitive on the market, and that increases the rates of mergers and acquisitions, privatizations, etc. (Thomas, 2002).

On the other hand the positive perspective of globalization remains the possibility of the transfer of capital and technology on a better market, the possibility of a faster trade due to the information technology, etc. (Dinello, Squire, 2005). One of the benefits of globalization is the possibility of choice, of which some of the states and even continents hadn't until now.

The best example in this case is Africa, a well shaped continent that hadn't the possibility of choice, and which is still suffering from the remains of the colonial period.

The conquest of Africa started from antiquity, but the major impact was caused by the economic competition and growth of the European capitalism. The most important moment, was the FrancoPrussian war in 1870, and the loss of Alsace and Lorraine which destroyed the French equilibrium and turned France's view to Africa in compensation. The trade competition generated a need for a bureaucratic structure, a modern military establishment, which wore sustained financially by the

\footnotetext{
${ }^{1}$ Faculty of History and Philosophy, "Babeș Bolyai" University, Cluj-Napoca, Romania.

2 “1 Decembrie 1918” University, Alba Iulia, Romania.
} 
owner states (Thomson, 2010) Nevertheless the impact of this strategy involved social movements, by the rebellions that started in different periods, which raised the costs of the administration. The battle for resources from gold to rubber, from tropical vegetable oils to minerals and iron realized one shore thing, the rise of importance of the settler community (n.r. we refer here to the period before the Second World War). The investments in the transport and irrigation sector, created a stable labor community, which hadn't felt the need of migration, and more important, a higher investment per capita, which was estimated in that period at $56 £$ in South Africa, $38 £$ in Zimbabwe and Zambia, and $13 £$ in the Belgian Congo (Crtin et all., 1982). Sectors like mineral production or oil extraction created a great interest for the European states; more over, agriculture generated waves of migration from Europe to Egypt, Maghrib and East Africa.

After the Second World War, new actors appeared on the international scene, where the United States of America and Japan, and even the Russian Federation, played an important role in the development or underdevelopment of the regions. The economic growth has been distributed in equal between different groups, the political struggle for power of these groups appeared more intensive and led to a poorer population, not richer (Kukkuk, 2005). The tired, exhausted and poorer labor force turned in to a violent strike, against the "European" colonialists. An important factor in the social movements was the slavery problem, which created migration waves from different regions, subject on which we won't insist very much on the current debate.

The forms of resistance to the European "regime" toke an interesting shape, and we can observe that a parallel political structure was created, with resistance political leaders, and the growth of nationalism in these regions (Schraeder, 2004). More over, we can observe the rise of riots, strikes and religious movements due to the diversity of the African population, the different economical policies that wore applied and the economical disparities that appeared in these territories. If we are going further with these analyses, we can sustain that the rapid decolonization of these territories, created a lack of stability in the regions, and generated conflicts and guerilla movements (Rothermund, 2006).

\section{Europe and the relations whit the African, Caribbean and Pacific Countries (ACP).}

Regarding the economical cooperation between the European Communities and ACP (n.r.After Lome IV ACP Countries are: Angola, Benin, Botswana, Burkina Faso, Burundi, Cameroon, Cape Verde, Central African Republic, Chad, Comoros, Congo (Brazzaville), Democratic Republic of Congo (Kinshasa), Cote d'Ivoire, Djibouti, Equatorial Guinea, Eritrea, Ethiopia, Gabon, Gambia, Ghana, GuineaBissau, Guinea, Kenya, Lesotho, Liberia, Madagascar, Malawi, Mali, Mauritania, Mauritius, Mozambique, Namibia, Niger, Nigeria, Rwanda, Sao Tome and Principe, Senegal, Seychelles, Sierra Leone, Somalia, South Africa, Sudan, Swaziland, United Republic of Tanzania, Togo, Uganda, Zambia, Zimbabwe, Antigua and Barbuda, The Bahamas, Barbados, Belize, Cuba, Dominica, Dominican Republic, Grenada, Guyana, Haiti, Jamaica, St. Kitts and Nevis, St. Lucia, St. Vincent and the Grenadines, Suriname, Trinidad and Tobag, Cook Islands, Federated States of Micronesia, Fiji, Kiribati, Marshall Islands, Nauru, Niue, Pacific Islands (Palau), Papua New Guinea, Solomon Islands, East Timor, Tonga, Tuvalu, Vanuatu and Samoa) [1] Countries, the Treaty of Rome (1957), defines the regime as overseas territories [2], which had a preferential trade agreement. The Yaounde Convention I and II, from 1963 and 1969, created the development of a free trade area and the accordance technical and financial aid, thru the European Development Fond and the European Investment Bank (Yaounde Convention, available at http://www.ena.lu/).

The Lome Convention I and II $(1975,1980)$, represents the renegotiation of the previous agreement by the elimination of trade barriers and the crystallization of common institutions such as the Ministerial Conference which covered in the terms of exports almost $99 \%$ of the exports of these countries (Barsan, 1999). Moreover by the STABEX system, financially sustained by the European Development Found, and compensated by the International Monetary Found, and by the SYSMIN system, the European Union ensures a highly stable platform of economical cooperation, which ensures a dependence rate on product of $15 \%$.The Financial Aid, in exchange, has a loan 
title, with a $1 \%$ rate in return, or $0.75 \%$, for the poorest countries for a period of 40 years.

Lome Agreements III and IV, suffered a change of optic, because the crash of prices for different products, because the economical stagnation of different countries, especially in the SubSaharan region.

The Cotonau Agreement and the EU- Africa strategic partnership of 2007 created a new perspective regarding the African and European Union relations. Due to highly increasing number of illegal immigrants, from Africa to Europe, and further more, due to all the global challenges that had been mentioned in the introduction, the European Union realized the risk of exposing to such waves, can represent threats regarding the internal security. Immigration and asylum create problems inside the EU and develop issues like housing, welfare, security, labor markets, heath and education. If we are analyzing the World Bank Report of April 2010, we can observe that the economic growth descended from 5.2 percent in 2008 to 1.6 percent in 2009 . The economy in this case, at a macro level is contracting, ant the implications could be catastrophic, because the cashflow in different sectors like infrastructure, industry and agricultural productivity are descending. The descending of capital in these sectors generates poverty and the direct result is migration. By analyzing the percentage of growth, this vector was situated at 3.1 percent in 2000, and raised to 6.1 in 2007 (World Bank Report, April 2010). The analysis of this growth allows us to assume that the capital flows and investments, along with the macro economical measures that had been taken, stabilized the social systems. The principal of human development seem to work in the case of Africa and the impact can be seen in the social vectors, such as HIV/AIDS, which has been stable, the enrolment in primary school increased (Kalipeni, 2004). The year of 2009, and the crisis threats, affected the remittance inflows have fallen from 4 to 8 percent.

Lending an borrowers in Africa from 2004-2009

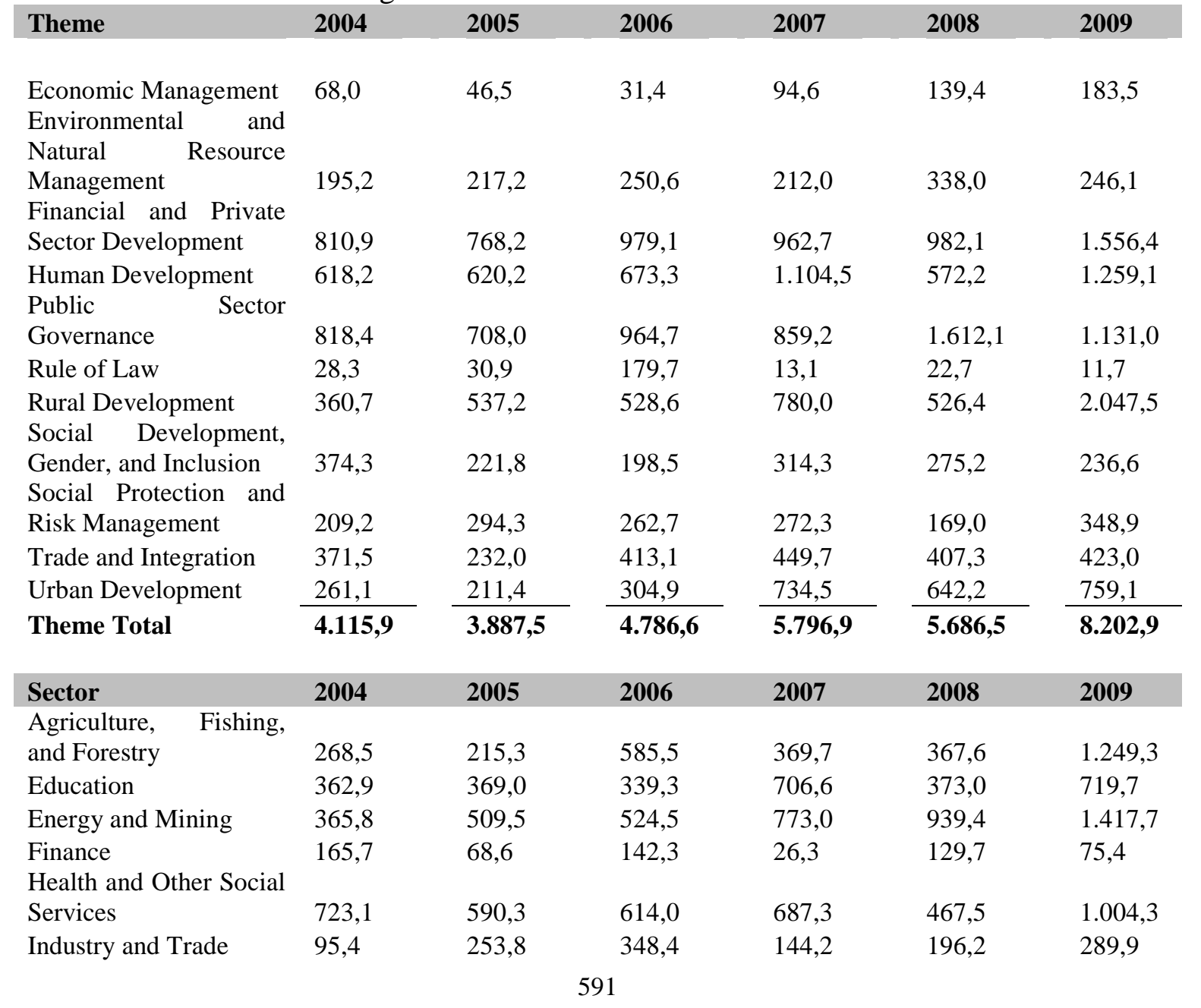




\begin{tabular}{|c|c|c|c|c|c|c|}
\hline $\begin{array}{l}\text { Information and } \\
\text { Communication }\end{array}$ & 52,9 & 20,0 & 5,0 & 146,0 & 0,8 & 144.3 \\
\hline Law and Justice and & & & & & & \\
\hline Public Administration & $1.004,2$ & $1.077,5$ & $1.263,0$ & $1.352,5$ & $1.748,0$ & $1.602,3$ \\
\hline $\begin{array}{l}\text { Transportation } \\
\text { Water Sanitation, and }\end{array}$ & 716,6 & 507,2 & 602,7 & 870,8 & 986,5 & $1.146,5$ \\
\hline $\begin{array}{l}\text { Water, Sanitation, and } \\
\text { Flood Protection }\end{array}$ & 360,8 & 276,2 & 361,9 & 720,5 & 477,9 & 553,6 \\
\hline Sector Total & $4.115,9$ & $3.887,5$ & $4.786,6$ & $5.796,9$ & $5.686,5$ & $8.202,9$ \\
\hline Of which IBRD & 0,0 & 0,0 & 40,0 & 37,5 & 30,0 & 361,5 \\
\hline Of which IDA & $4.115,9$ & $3.887,5$ & $4.746,6$ & $5.759,4$ & $5.656,5$ & $7.841,4$ \\
\hline
\end{tabular}

Source: Report of the World Bank regarding lending an borrowers in Africa from 2004-2009, available at http://siteresources.worldbank.org/EXTAR2009/Resources/6223977-1253132981998/64403711253210685497/Lending_Them, 30 august 2010

If we are taking a closer look at the report, we can observe the implications that the African Economy had suffered, and the most affected sector represents the rural development. Regarding the World Bank Report, and if we are regarding the export volume of goods, and correlated with the debt of different states, we can notice that at a macro level, we can conclude that the economies of these states are small economies, and international trade can induce fluctuations in these sectors. Moreover, the main exports are intermediated inputs, (United Nations, 2009) and if we go further and link with the high level of exports with the debt of the states, we can conclude that most of the outcomes of exports are returned to pay the external debts.

The conclusion in this case is that the African states should consider a top priority the consolidation of the macro economy, by focusing at the fiscal stabilization, by liberalization of exported goods, the deregulation of the private sector, and the liberalization of internal markets.

Possible measures in this case could be taken, such as the reduction of liquidity on the market, a policy that we can find sustained by many economists, including Paul Krugman. Another measure that can be taken into consideration is the increasing of the cost of credit, and by that, the raise of interest rates. One of the last measures that can be taken into consideration represents the raise of bank reserve requirements, requiring holding more government securities. Another possibility in this case is the creation of a monetary unique currency, in a central bank, that gives credibility of trade, and even work as a macro economical instrument and an agent of restraint for the independent fiscal and monetary stance. As an argument in this sense, if we are focusing our attention to the inflation differentials and the role of the exchange rate, we can sustain that a unique monetary currency will have positive effect. The so called ex post phenomenon (e.g. DIVERGENT INFLATION RATES IN EMU) [3], present in the African macro economy, gives us a couple of answers about the effects of inflations. In the absence of the adjustment of the nominal exchange rate, the real appreciation is generated by the above average inflation; in this case, a real appreciation is generated by the above average inflation (Krugman, 2009).

If we are looking from a different perspective, and we are starting from a simple gravity model regarding trade flows to different regions, and different sizes, to which we add different variables, like the participation in free trade agreements and possible valuation effects, we are allowed to discuss the range of issues related to the transition process in which the African countries are related. On another hand, the economical instability of the African states, in the present case, represent a threat to the European Union, from the perspective of labor movement and migration. 


\section{References}

[1] http://ec.europa.eu/development/geographical/regionscountries_en.cfm accessed in 22 august 2010;

[2] http://www.hri.org/docs/Rome57/Part4.html\#Pt4 , article 131-136 accessed in 22 august 2010;

[3] DIVERGENT INFLATION RATES IN EMU*Patrick Honohan, World Bank and CEPRPhilip R. Lane, Trinity College Dublin and CEPR, available at: http://www.tcd.ie/Economics/TEP/2003_papers/TEPNo4PL23.pdf accesed in 01. September 2010.

[4] Barsan M., 1999. Integrare Economica Europeana, Vol II, Editura Fundatiei Maramures, Baia Mare.

[5] Braverman H., 1998. Labor and Monopoly Capital, Monthly Reviewed Press, NY.

[6] Ohmae K, 1995. The end of the nation state, Cambridge, MA, Free Press.

[7] David, Thomas C, Essentials of International Management, Sage Publications, London 2002

[8] Curtin Ph., Feirman S., Thomson L., Jan V., 1982. African History, Longman Group, third Edition, Essex.

[9] Kennedy P., 1997. Macroeconomic Essentials for Media Interpretation, The MIT Press, Cambridge.

[10] Krugman P., 2009. Intoarcerea Economiei declinului si criza din 2008, ed. Publica, Bucuresti.

[11] Rosenbaum D.,Market Dominance, Praeger Publishers, Westport, 1998.

[12] Dinello N., Squire L, Globalization and equity: perspective from the developing world, Edward Elgar Publishing, Massachusetts, 2005.

[13] Thomson A., An Introduction to African Politics, Routledge NY, 2010.

[14] Leon Kukkuk Letters to Gabriella: Angola's Last War for Peace, What the Un Did And Why, FLF Press, Sarasota, 2005.

[15] Peter J. Schraeder African Politics and Society, Thomson/Wadsworth, 2004.

[16] Dietmar Rothermund. The Routledge companion to decolonization, Routlage Group, NY, 2006.

[17] Ezekiel Kalipeni, HIV and AIDS in Africa: beyond epidemiology. Blackwell Publishing Ltd. Oxford, 2004.

[18] United Nations, Industrial Development Report 2009: Breaking In and Moving Up 2009

[19] http://ec.europa.eu/development/geographical/regionscountries_en.cfm

[20] http://www.hri.org/docs/Rome57/Part4.html\#Pt4

[21] http://www.ena.lu/

[22] http://siteresources.worldbank.org/EXTAR2009/Resources/6223977-1253132981998/64403711253210685497/Lending Them

[23] http://www.tcd.ie/Economics/TEP/2003_papers/TEPNo4PL23.pdf 